SHS Web of Conferences 10, 00017 (2014)

DOI: $10.1051 /$ shsconf $/ 20141000017$

C Owned by the authors, published by EDP Sciences, 2014

\title{
Object and subject of evasion of taxes and other compulsory payments
}

\author{
L. Koval \\ University of Latvia, Latvia
}

\begin{abstract}
The paper is devoted to such topical issue of Criminal Law as Object and Subject of Evasion of Taxes and Other Compulsory Payments. There are analyzed researched crime determination problems, which are connected with subject and object of tax and other compulsory payments evasion. In the course of the research, the author has made the conclusions that the object of the evasion of taxes and other compulsory payments group is the national economic interests. The direct object is the national economic interests in the sphere of state revenues or the national fiscal interests. While analyzing the law and regulations it is concluded that the subject of the evasion of taxes and other compulsory payments is the tax base (income, property, expenses and consumption), taxes, state and local government fees, as well as other payments determined by the State. The author has also concluded that the subject of the evasion of taxes and other compulsory payments does not include increase in the tax principal debt, fine and late charge, which are covered by the financial responsibility. The subject of the evasion of taxes and other compulsory payments may not include also income from illegal activity or proceeds resulting from criminal offences.
\end{abstract}

\section{Introduction}

Taxes are the main income for a country, which ensures its development and welfare. In the period of economic instability the problem of evasion of taxes becomes more topical, since the national budget revenues and the economic recovery in general depend largely on the solution of that problem. Lawmakers protect national interests, providing for criminal responsibility for the evasion of taxes and other compulsory payments. For the correct classification of the criminal offence, there shall be established and evaluated all its constituent elements. In order to precisely define interests affected by the criminal offence and the harm resulting from it, the object and the subject of the criminal offence shall be analyzed. The goal of this research is to research the object and the subject of the evasion of taxes and other compulsory payments, analyzing their meanings and elements.

\section{Materials and methods}

Fundamental researches of domestic and foreign criminal law scientists and normative regulations are analyzed with dogmatic, historical, logical, comparative, systematic, analysis and synthesis method to achieve the aim of research.

This is an Open Access article distributed under the terms of the Creative Commons Attribution License 4.0, which permits unrestricted use, distribution, and reproduction in any medium, provided the original work is properly cited. 


\section{SHS Web of Conferences}

\section{Results and discussion}

1. Object of Evasion of Taxes and Other Compulsory Payments

Evasion of taxes and other compulsory payments is a crime. Its object is national economic interests. This criminal offence is classified in the criminal law according to the object of the criminal offence as crimes against economy. However, there is not developed a grounded and adequate notion crimes against economy. It is due to the contents of the object of crimes. National economic interests and normal development of the national economy are endangered not only in the crimes included in Chapter XIX of the Criminal Law, but also in other crimes included in other chapters of the Criminal Law.

Legal literature sets out the opinions that evasion of taxes and other compulsory payments shall be also classified as offences against the local government order. K. Mamilovs believes that "the meaning of tax as a public legal duty set out in law allows to state that its non-fulfillment shall be classified as an offence against the State, representing in this certain case interests of all members of the society" (Мамилов, 2001).

The aforesaid opinion of Russian scientists is not recognized in the Latvian Criminal Law doctrine. According to Dr. habil. jur. prof. U. Krastinsš “classification of certain criminal offences as crimes against economy would be facilitated if those would include only such crimes as set out in a separate chapter of the Criminal Law named respectively. However, there is no such an all-embracing chapter in the Criminal Law. It is explained by the fact that not all crimes endangering the national economic interests are oriented only against such interests, and economic interests are not always the main aspect against which a certain offence, e.g., bribery, extortion, fraud, forging of official documents, etc., is committed" (Krastiņš and Joksts, 1997).

Legal literature contains the opinion that crimes against economy include such criminal offences as set out in the chapter on economic crimes. Title of relevant chapter of the Criminal Law of Latvia (hereinafter referred to as the CL) is Offences against the National Economy. The object of this group of crimes is the national interests in general, while the direct object of each criminal offence is interests of normal operation of a certain industry in the national economy. It should be concluded that crimes against economy endanger the national economic interests in the spheres of production, exchange and distribution of material values. Certainly, among these spheres there can be distinguished more specific fields of the national economy - property, entrepreneurship, finances, taxes, trade, agriculture, industry, transport, natural resources, etc. For example, the direct object of smuggling (Sect. 190, CL) is the national interests in the sphere of the customs operations, the direct object of the manufacture and distribution of counterfeit money and state financial instruments (Sect. 192, CL) is the national financial and monetary interests, the direct object of laundering of the proceeds from crime (Section 195, CL) is the national interests in the finance - loan and fiscal sphere.

At the same time, the general object of the evasion of taxes and other compulsory payments is the national economic interests, and the direct object is the national economic interests in the sphere of national revenues or the national fiscal interests.

Evasion of taxes and other compulsory payments are related to the national social and political spheres. It can be also related to other criminal offences, such as laundering of the proceeds from crime, smuggling, crimes related to the illegal circulation of narcotic substances and weapons.

In resuming, it should be concluded that the object of the evasion of taxes and other compulsory payments is the national economic interests in the sphere of national revenues, violation of which leads to drastic consequences not only in the national economy, but also in the political, social and criminal sphere.

2. Subject of Evasion of Taxes and Other Compulsory Payments

The object of the evasion of taxes and other compulsory payments is directly related to its subject. The subject of the evasion of taxes and other compulsory payments includes taxes set out in law, taxable income, profit and other taxable objects, as well as other compulsory payments. 
Int. Conf. SOCIETY. HEALTH. WELFARE.

The subject of the evasion of taxes and other compulsory payments:

$>$ tax;

$>$ taxable objects, or tax base;

$>$ other compulsory payments or state or local government fees.

In order to understand the essence of the subject of the evasion of taxes and other compulsory payments, there should be discussed separately each possible element of the subject.

2.1. Tax

Special literature offers several definitions of tax. So, e.g., tax is defined as a source for the budget revenues. Taxes are also classified as a fiscal policy instrument. In other sources taxes are defined as mandatory payments into the budget in order to ensure the performance of the national functions, however, they are not related to receipt of a certain service or product. This quite a popular definition of tax contains some significant element, which differs tax from price. There exists also an opinion that "taxes are mandatory monetary payments into the state budget, which are regularly made by any income-earning person" (Lukašina, 2003). Nonetheless, the more precise definition from the point of view of law is given in Section 1 of the law On Taxes and Fees.

Pursuant to that Section, tax is a mandatory payment into the State budget or local government budgets (basic budget or special budget) provided for by law, which is not payable for the acquisition of specific goods or receipt of services and is not a payment of a fine and a late charge, nor a payment for the use of State capital or part thereof. The term mentioned shall also apply to mandatory contributions for State social insurance, as well as for the customs taxes and other compulsory payments as set out in the directly applicable regulatory enactments of the European Union about the customs matters (Latvian Republic law On Taxes and Fees, 1995).

The lawmaker used in the definition positive and negative explanation. The legal definition differs the meaning of tax from payment for services, fine, late charge, price and other similar meanings.

Thus, the following features are attributable to tax:

$>$ mandatory nature;

$>$ lawfulness (tax is determined by law);

$>$ payment into the State budget or the local government budgets.

State taxes in general form a single system. Latvian system of taxes and fees presently includes 14 taxes, state fees, local government fees and the taxes set out in the directly applicable regulatory enactments of the European Union. The system is regulated by the law On Taxes and Fees, as well as the tax and fee laws, the Cabinet regulations, binding regulations issued by the local government council and directly applicable regulatory enactments of the European Union.

Taxes are direct and indirect. Direct tax is a tax payable by the income recipient or the owner of a taxable object. Direct taxes in Latvia are individual income tax, enterprise income tax, social payments, natural resource tax, lottery and gambling tax, passenger car and motorbike tax, real estate tax, electric power tax, vehicle operation tax and enterprise passenger vehicle tax. Indirect tax is a tax payable into the budget through the mediator. Indirect taxes are determined as price markup in percentage or in absolute sum. Buyer pays tax included in price and gives it to seller, and seller, in its turn, pays tax into the budget. There is formed an inter-link - in fact, tax is paid by the buyer, however the seller pays it into the budget (Lukašina, 2003). In Latvia this is attributable to the customs, excise and value-added tax.

In the Republic of Latvia, 14 taxes are determined, which are calculated, paid, collected and administrated in accordance with the procedure set out in relevant tax law.

Researching and analyzing the legal practice in the Republic of Latvia, it has been established that value-added tax, individual income tax, state social insurance mandatory payments and enterprise income tax become more often the subject of the evasion of taxes and other compulsory payments. 


\section{SHS Web of Conferences}

\subsection{Tax Base}

The subject of the analyzed crime can be also taxable income, profit and other objects. All such objects form the tax base. The tax base is the tax element, and in respect of different taxes there are different objects. The tax base is a taxable benefit of financial nature, with the type of tax determined by the national law. The tax base is extensive and diverse. Uniting all tax objects according to the uniform features, there can be formed three main groups:

1) income;

2) property;

3) expenses or consumption. (Zvejnieks, 1998).

The tax base is determined by each relevant tax law, regulating tax rate, benefits and taxpayer, as well as other conditions related to the calculation and payment of taxes. Each tax, pursuant to the normative regulation, has its base and it can be also differentiated according to the status of a taxpayer, thus, the range of all tax bases is very extensive. In order to illustrate the tax base, there can be mentioned several examples of tax bases. For example, the object of the enterprise income tax for residents is taxable income earned within the taxation period in Latvia and abroad (Latvian Republic law On Enterprise Income Tax, 1995). Enterprise income tax applies to the taxpayer's income earned within the taxation period. The tax base is financial profit of the enterprise, which is adjusted pursuant to law. Adjustments are mainly made in order to increase profit by the expenses not recognized for the tax needs (for example, expenses not related to economic activity), or to reduce profit by relevant sums, if the law provides for tax relieves. At the same time, the immovable property tax base is cadastral value of immovable property. Cadastral value of immovable property is determined in accordance with the immovable property market value. The amount of the immovable property tax is directly proportional to the property value. Valueadded tax applies to all consumptions, i.e., all goods and services, except for a very limited number of exemptions set out in law. Value-added tax applies to the transactions set out in Section 2 of the Value-Added Tax Law, thus, the tax base is the transaction value.

Scientists argue whether income resulting from illegal activities, e.g., entrepreneurship without registration and without license, is taxable or not.

So, according to the opinion of the Supreme Court of the Russian Federation expressed in Decision No. 8 adopted at its plenary meeting on 04 June, 1997 About various matters regarding the application of the criminal law norms regarding the responsibility for the evasion of taxes and other compulsory payments in courts of the Russian Federation, that the activities of the entity engaged in entrepreneurial activity without registration or without license and not paying taxes on income resulting from the aforesaid activities shall be classified as the aggregation of criminal offences as provided for in Sections 171 and 198 of the Criminal Law of the Russian Federation (entrepreneurship without registration and without license and evasion of taxes and other compulsory payments). The Supreme Court's of the Russian Federation Decision No. 8 is lapsed at the moment, but it caused lot of discussions among criminal law scientists.

At the same time, many criminal law scientists do not recognize this opinion as reasonable. For example, R. Smakov believes that the entity's activities should be classified as entrepreneurial activity without registration or without license. R. Smakov substantiates his point of view by the fact that "first, all income resulting from illegal activities is confiscated in favor of the State, thus, it is not clear how taxes on it can be collected, and second, if the State agrees to apply taxes to the income resulting from illegal activities, then the State as if legalizes the criminal offence itself (Смаков, 1997).

Other criminal law scientists agree to R. Smakov's opinion, supplementing it by other arguments: "From the point of view of the criminal law, entrepreneurship without registration or without license is a criminal offence like illegal circulation of narcotic substances, weapons, smuggling, bribery, etc., thus, income from the entrepreneurship without registration and other crimes listed above is earned illegally. Recognizing it necessary to pay taxes on income resulting from unregistered entrepreneurial activity, 


\section{Int. Conf. SOCIETY. HEALTH. WELFARE.}

there shall be observed the succession and recognized as necessary to pay taxes in all the cases of illicit gain" (Волженкин, 2002).

I. Kucherov writes in his work Crimes in the Taxation Sphere, i.e., profit earned from illegal entrepreneurial activity, i.e. earned from the entrepreneurial activity without registration of the economic subject or without relevant license may not be classified as a taxable object. Thus, the person earning it has no duty to pay tax" (Кучеров, 1999).

N. Lopashenko states that such criminal offence as entrepreneurial activity without registration or without license is inseparably related to non-payment of taxes. According to N. Lopashenko's opinion, entrepreneurial activity without paying taxes should be classified either as entrepreneurial activity without registration, if the entrepreneurial activity carrying out procedure is violated, or as evasion of taxes and other compulsory payments, if the person is engaged in entrepreneurial activity on a lawful basis (Волженкин, 2002).

The author of the research believes that the opinions of the aforesaid scientists should be supported, since taxation of illegally earned income conflicts with the norms of morality. Illegal economic activity is not regulated by law, it can be related only to the criminal responsibility, and the national financial interests are protected by the recovery in favor of the State, if entrepreneurial activity is carried out without registration or without license. Apart from that, one should also take into account that the subject of the evasion of taxes and other compulsory payments do not include the increase in the principal debt related to taxes, fine and late charge included in the financial responsibility. Financial responsibility is provided for in law On Taxes and Fees.

2.3. Other Compulsory Payments

It is not exactly defined in the law which are payments imposed together with taxes. In practice such definition is attributable to the state and local government fees. It would not be acceptable to equate to taxes such payments as increase in the tax principal debt, fine, late charge or other sanctions other than taxes or fees. Thus, the amount of losses in relation to which the accusation is made, shall be stated only in the amount of unpaid taxes.

Analyzing the law practice of the Republic of Latvia, it has been concluded that criminal offence shall be classified pursuant to Section 218 of the CL not only where the criminal offence subject evades taxes, but also where the criminal offence subject evades the state and the local government fee payments.

Section 218 of the CL provides for the responsibility also for non-payment of state fess, local government fees and other state mandatory payments.

Fees like tax are also monetary payments, however they are paid into the budget not for relevant person has earned income, but for it received any service from the state or local government institutions. Fee is a payment by individuals or legal entities to the State or local government for the services (Lukašina, 2003). The lawmaker provides a legal definition of the state and local government fee in the law On Taxes and Fees.

State fee is a mandatory payment into the State budget (basic budget or special budget) or in the cases provided for by the law On Taxes and Fees into the local government budget as remuneration for funding that State institutions have given for economic activity, or for services provided and special purposes set out in laws (Latvian Republic law On Taxes and Fees, 1995).

The difference between the State fee and the local government fee is that the state fee is determined in laws by the Parliament (Saeima) or in the Cabinet of Ministers' Regulations by the Cabinet of Ministers, in its turn; the local government fees are determined by the local government council in the local government's binding regulations. The local government fee is a mandatory payment into the local government basic budget or special budget as determined by the local government council in cases provided for in the law On Taxes and Fees (Latvian Republic law On Taxes and Fees, 1995). 
SHS Web of Conferences

\section{Conclusions}

In conclusion of the research it is summarized that it is necessary to improve situation with tax and other compulsory payments evasion for protection of state financial interests, public welfare and social security development. One of the important ways of improving of situation with tax payment is successful enforcement of tax evasion. In the course of the research, the author has made the following conclusions, which helps to solve such qualification problems as detection of subject and object of tax evasion:

1. The object of the evasion of taxes and other compulsory payments group is the national economic interests, and the direct object is the national economic interests in the sphere of state revenues or the national fiscal interests.

2. The subject of the evasion of taxes and other compulsory payments is the tax base (income, property, expenses and consumption), taxes, state and local government fees, as well as other payments determined by the State.

3. The subject of the evasion of taxes and other compulsory payments does not include increase in the tax principal debt, fine and late charge, which are covered by the financial responsibility.

4. The subject of the evasion of taxes and other compulsory payments may not include also income from illegal activity or proceeds resulting from criminal offences.

\section{References}

[1] Krastinsš, U., Joksts, O. (1997.) Noziegumi ekonomikā [Economic crimes]. Rīga: LPA, 162 lpp. (in Latvian)

[2] Lukašina, O. (2003.) Nodokï Latvijā: analīze un praktiskie ieteikumi - 2 (papildināts un izlabots izdevums) [Taxes in Latvia: analysis and practical recommendations - 2 (updated and corrected edition)]. Rīga: Merkūrijs LAT, 263 lpp. (in Latvian)

[3] Par nodokliem un nodevām [On Taxes and Fees]: LR likums. Latvijas Vēstnesis, 1995. 18.februāris, nr.26 (309). (in Latvian)

[4] Par uzñ̄emumu ienākuma nodokli [On Enterprise Income Tax]: LR likums. Latvijas Vēstnesis, 1995. 1.marts, nr. 32 (315). (in Latvian)

[5] Zvejnieks, A. (1998.) Nodokï un nodevas mācību grāmata - 2 (pārstrādātais un izlabotais izdevums) [Taxes and fees textbook - 2 (revised and corrected edition)]. Rīga: RTU, 412 lpp. (in Latvian)

[6] Волженкин, Б. В (2002) Преступления в сфере экономической деятельности [Crimes in the sphere of economic activity]. Санкт-Петербург: Юридический центр Пресс, 641 с. (in Russian)

[7] Кучеров, И.И. (1999) Преступления в сфере налогообложения. Научнопрактический комментарий к УК РФ [Crimes in the taxation sphere. Scientific and practical commentary to the CC of RF]. Москва, 376 c. (in Russian)

[8] Мамилов, К.В. (2001) Уголовно-правовое основание уголовной ответственности за уклонение от налогов [Criminal legal basis of criminal liability for tax evasion]. Ижевск, $172 \mathrm{c.}$ (in Russian)

[9] Смаков, Р. (1997) Верховный суд вглядывается в физические лииа [Supreme Court looks into individuals]. Москва: Российская газета, 1997 г. 5 июля. (in Russian) 